Gyllenberg, H., Rossander, M. \& Roine, P. (1953). J. gen. Microbiol. 9, 190-198.

\title{
A Strain of Lactobacillus bifidus which requires Strepogenin
}

\author{
By H. GYLLENBERG, MARJATTA ROSSANDER AND P. ROINE \\ Department of Nutritional Chemistry, University of Helsinki, Finland
}

SUMMARY : A strain of Lactobacillus bifidus was isolated from the faeces of a breastfed infant and subcultivated in the minimal medium of Hassinen, Durbin, Tomarelli \& Bernhart (1951). The cysteine requirement for maximal growth of the strain was c. $100 \mu \mathrm{g}$. cysteine/ml. Human and cow milk were found to contain another factor, besides cysteine, which was essential for optimal growth. The active material in milk could be replaced by enzymic hydrolysates of some commercial proteins; egg albumin, and blood albumin were the most potent sources. The active material was heat stable, but was completely inactivated by treatment with strong acid. All the properties of this active material studied showed a close resemblance to those of strepogenin.

Until recent years some confusion has existed regarding the definition of the term Lactobacillus bifidus. This is especially true concerning the relations of the strains investigated to Tissier's $(1899,1900)$ original Bacillus bifidus communis. Many strains with different properties have been claimed as the authentic $L$. bifidus in the sense of Tissier's description. This confusion seems to have been cleared up by the investigations of Norris, Flanders, Tomarelli.\& György (1950). They found that strains which on isolation exhibited a typical bifid morphology rapidly changed to straight rods of common lactobacillus type when subcultivated in complex organic media. A change took place also in their relation to atmospheric oxygen, the originally anaerobic or microaerophilic strains becoming capable of aerobic growth. When, however, subcultivation was carried out in the simplified medium of Teply \& Elvehjem (1945) the original properties remained unchanged for practically unlimited periods of time. Since the properties of the unchanged type agree with those of Tissier's B. bifidus communis, it should, according to Norris et al. (1950), be named Lactobacillus bifidus, and the straight rod type, since it is a variety of the unchanged type, Lactobacillus parabifidus. This suggested nomenclature is the reverse of that in the current edition of Bergey's Manual (1948). The description of $L$. bifidus in Bergey's Manual is based on the investigation of Weiss \& Rettger (1938). The importance of a carefully controlled isolation and subcultivation technique was evidently overlooked by earlier investigators, a fact which possibly explains the disagreement between their results.

For strains of the straight rod type Tomarelli and his co-workers (1949a, $1949 b, 1950)$ demonstrated nutritional requirements which closely resemble those of other lactobacilli. For example, deoxyribonucleic acid derivatives as well as unsaturated fatty acids are required by this type of $L$. bifidus. The nutritional requirements of the bifid type seem to be simpler. Hassinen 
et al. (1951) found that in a medium containing cystine (or cysteine) strains of the bifid type utilized ammonium salts as a nitrogen source. Of the B-group vitamins only biotin and pantothenic acid were required; purine and pyrimidine compounds were not essential for the strains studied. Tomarelli et al. (1950) found that unsaturated fatty acids were required by the bifid type also, when the medium contained no acetate.

Hassinen et al. (1951) found that the bifid type remained unchanged in minimal nutrient media. Accordingly, it seems evident that continuous subcultivation under these conditions prevented change in the nutritional requirements of $\boldsymbol{L}$. bifidus. While investigating a strain of $L$. bifidus isolated and subcultivated under the conditions described by Hassinen et al. (1951), the present authors found that their strain required milk as a supplement to the basal medium. The investigations described below were carried out in order to explore this observation.

\section{EXPERIMENTAL}

\section{Methods}

The strain TM 2 of $L$. bifidus used chiefly was isolated from the faeces of a breast-fed infant by means of the medium of Hassinen et al. (1951). In agreement with Hassinen et al. (1951) only typical L. bifidus colonies grew on this medium. No growth was observed under aerobic conditions and no production of carbon dioxide could be demonstrated. Certain pentoses in addition to the usual hexoses and disaccharides were fermented; the fermentation products were not analysed.

In experiments on nutritional requirements of the isolated strains inoculation of the assay tubes was carried out from saline suspensions of cells. Anaerobic conditions were obtained by pouring melted paraffin into each tube and allowing it to solidify on the liquid surface, thus forming a plug. The tubes were incubated at $37^{\circ}$ for $65-70 \mathrm{hr}$. A measure of growth was obtained by titration of the acid produced; this was not calibrated against increase of cell mass or turbidity.

In investigating the strepogenin activity of protein hydrolysates some experiments with $L$. casei (ATCC 7469) were performed according to Kodicek \& Mistry (1952) and with the medium of Clegg, Kodicek \& Mistry (1952), but the growth was measured by titration of acid after $48 \mathrm{hr}$. growth, and not turbidimetrically as proposed by these authors for the strepogenin assay.

The whey used in some experiments was prepared as follows. Milk was curdled with rennet and the coagulum removed by filtration through a cloth. The filtrate was adjusted to $c . \mathrm{pH} 5 \cdot 2$ by addition of dilute acetic acid. This treatment gave a lactalbumin precipitate which was filtered off. This filtrate was readjusted to $\mathrm{pH} \mathrm{5.2}$ with acetic acid and brought to the boil. Additional protein (lactoglobulin) was thereby precipitated and filtered off. The remaining greenish-yellow clear liquid still contained $0 \cdot 6-0.65 \mathrm{mg} . \mathrm{N} / \mathrm{ml}$., and remained clear on further addition of acetic acid. 


\section{Cysteine (cystine) requirement}

While studying the growth of freshly isolated $L$. bifidus strains in human or cow milk it was observed that growth in human milk was greatly improved when prolonged heating at $63^{\circ}$ was used for 'sterilization' instead of autoclaving (Table 1 ). When cysteine was added to the milk, however, no distinct difference could be found in acid production as between autoclaved milk or milks heated to $63^{\circ}$. Thus it appeared that the strains were dependent on the presence of cysteine in the medium, and that autoclaving made cysteine unavailable. Similar observations were also made when autoclaved milk or milks heated at $63^{\circ}$ were added as supplements to the basal medium for L. bifidus when prepared cysteine-free (Fig. 1). Here again autoclaved human milk was distinctly less active in replacing cysteine in this medium. Cow milk seemed to contain, even when not autoclaved, only very small amounts of material which could replace cysteine for $L$. bifidus, as compared with human milk. This is noteworthy since cow milk contains about the same total amount of cysteine (cystine) as human milk.

Table 1. Effect of different heat treatments of human milk on the growth of $\mathrm{L}$. bifidus (TM 2 and $K A$ 2)

\begin{tabular}{|c|c|c|c|}
\hline \multicolumn{2}{|c|}{ Strain TM2 } & \multicolumn{2}{|c|}{ Strain KA2 } \\
\hline $\begin{array}{l}\text { Milk heated } \\
10 \text { min. at } \\
110^{\circ}\end{array}$ & $\begin{array}{c}\text { Milk heated } \\
30 \text { min. at } \\
63^{\circ}\end{array}$ & $\begin{array}{l}\text { Milk heated } \\
10 \text { min. at } \\
110^{\circ}\end{array}$ & $\begin{array}{l}\text { Milk heated } \\
30 \text { min. at } \\
{63^{\circ}}^{\circ}\end{array}$ \\
\hline \multicolumn{4}{|c|}{ ml. $0 \cdot 1 \mathrm{~N}-\mathrm{NaOH} / 10 \mathrm{ml}$. milk } \\
\hline $2 \cdot 0$ & 1.0 & 2.0 & 1.0 \\
\hline $7 \cdot 9$ & $14 \cdot 2$ & $7 \cdot 6$ & $14 \cdot 3$ \\
\hline $19 \cdot 0$ & $16 \cdot 8$ & $15 \cdot 8$ & $16 \cdot 6$ \\
\hline
\end{tabular}

Blank (not inoculated)

Human milk

Human milk + cysteine (200 $\mu \mathrm{g} . / \mathrm{ml}$.

Further experiments showed that addition of cysteine alone to the medium did not produce maximal growth. As can be seen from Table 2, small amounts of milk had a distinct growth-promoting effect independent of the kind of heat treatment or of milk. This effect appeared to be due to an additional essential factor, and the cysteine requirement could be determined only when the basal medium contained a supplement of this factor. The medium was therefore modified by an addition of a small amount of autoclaved cow milk, the cysteine activity of which was negligible (Fig. 1). With this supplemented medium the minimum cysteine requirement of the test strains was $c .100 \mu \mathrm{g}$. cysteine/ml. medium (Fig. 2).

\section{Requirement for the additional factor present in milk}

The additional effect of milk, apart from that due to cysteine, is shown in Table 2. The curves in Figs. 3 and 4 show that there was a direct relationship between the amount of milk and the growth of test organism. It can be seen, also, that the active factor of milk is heat stable: the same effect was obtained 
whether or not the milk was autoclaved. After partial removal of the protein the active factor was found in the whey.

Experiments were carried out in order to establish the nature of the active substance. The results are tabulated in Table 3. It was found that the growthpromoting activity of milk (and whey) was not due to any vitamin of the

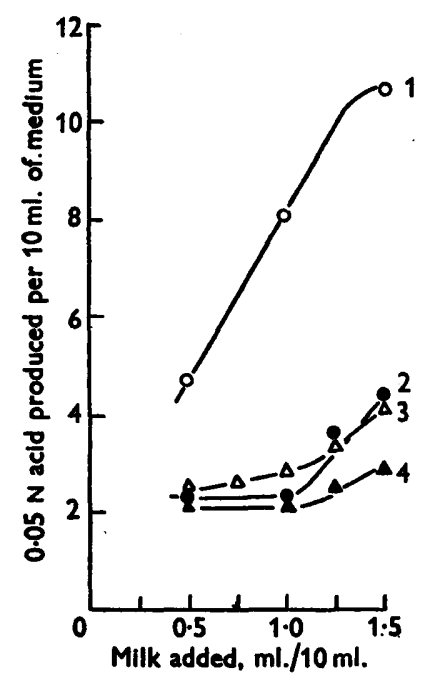

Fig. 1

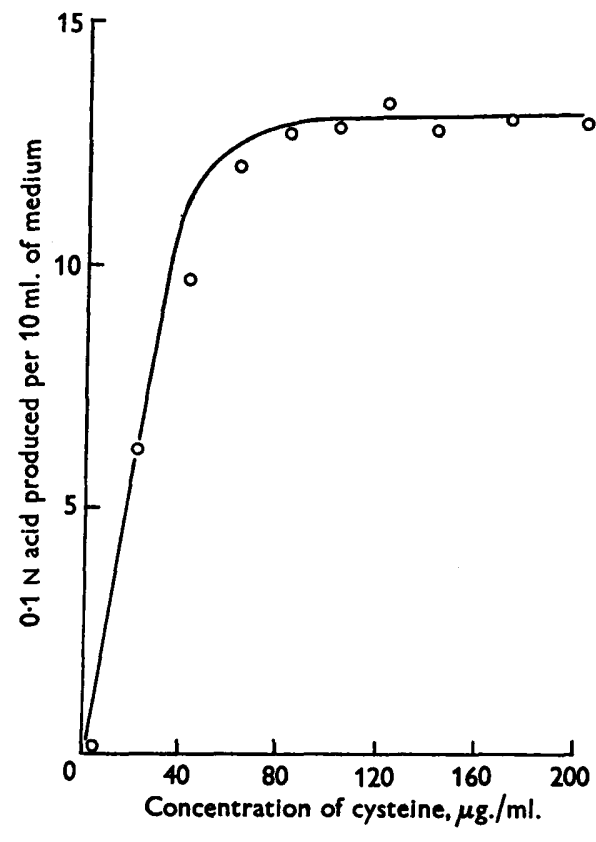

Fig. 2

Fig. 1. Effect of human milk or cow milk on the growth of $L$. bifidus (TM2) in a medium containing no cysteine. 1. Human milk, heated for $30 \mathrm{~min}$. at $63^{\circ}$. 2. Human milk, heated for $10 \mathrm{~min}$. at $110^{\circ}$. 3. Cow milk, heated for $30 \mathrm{~min}$. at $63^{\circ}$. 4. Cow milk, heated for $10 \mathrm{~min}$. at $110^{\circ}$.

Fig. 2. Effect of cysteine on the growth of L. bifidus (TM2).

Table 2. Effect of small additions of milk on the growth of $\mathbf{L}$. bifidus ( $T M 2$ and $K A 2$ ) in the basal medium containing cysteine

\author{
Additions to basal medium \\ Nil \\ Cysteine, $80 \mu \mathrm{g} . / \mathrm{ml}$. \\ Ditto $+0.5 \mathrm{ml} . / 10 \mathrm{ml}$. unautoclaved human milk \\ Ditto + 0.5 ml. $110 \mathrm{ml}$. autoclaved human milk \\ Ditto + 0.5 ml./10 ml. autoclaved cow milk
}

Strain TM2 Strain KA2 ml. $0 \cdot 1 \mathrm{~N}-\mathrm{NaOH} / 10 \mathrm{ml}$. medium

B-complex, nucleic acid derivatives, components of the milk ash, or fatty acids (Tween 80). Amino-acid mixtures prepared to simulate the aminoacid composition of milk and some milk fractions were also inactive. The only preparations which showed activity in the first experiments were tryptic digests of casein and lactalbumin separated from milk. Accordingly, similar 
Table 3. Effect of different additions on the growth of $\mathbf{L}$. bifidus (TM 2) in the basal medium

Supplement/10 ml. basal medium

1. Cow milk $(0.2 \mathrm{ml}$.)

2. Whey $(=0.2 \mathrm{ml}$. milk)

3. Tryptic digest* of casein separated from milk ( $=0 \cdot 2 \mathrm{ml}$. milk)

4. Tryptic digest of lactalbumin separated from milk $(=0 \cdot 2 \mathrm{ml}$. milk)

5. Tryptic digest of whey $(=0 \cdot 2 \mathrm{ml}$. milk)

6. Tryptic digest of commercial casein $(0.2 \mathrm{ml}$.)

7. Tryptic digest of egg albumin $(0 \cdot 2 \mathrm{ml}$.)

8. Tryptic digest of blood albumin $(0.2 \mathrm{ml}$.)

9. Tryptic digest of pepsin $(0.2 \mathrm{ml}$.)

10. Tryptic digest of gelatin $(0.2 \mathrm{ml}$.)

11. Tryptic digest of zein $(0 \cdot 2 \mathrm{ml}$.)

12. Trypsin solution* $(0 \cdot 2 \mathrm{ml}$.)

13. Mixture of B-vitamins $\dagger(0 \cdot 2 \mathrm{ml}$.)

14. Mixture of nucleotides $\dagger(0 \cdot 2 \mathrm{ml}$.)

15. (13) $+(14)(0.2 \mathrm{ml}$. of each)

16. Tween $80(0.1 \mathrm{ml}$.

17. Ash of cow milk $(=0.2 \mathrm{ml}$. milk)

18. Mixture of amino-acids $\dagger(0 \cdot 2 \mathrm{ml}$.)

\begin{tabular}{|c|c|c|}
\hline Exp. 1 & Exp. 2 & Exp. 3 \\
\hline $12 \cdot 8$ & $15 \cdot 3$ & $12 \cdot 6$ \\
\hline$\cdots$ & $14 \cdot 6$ & $10 \cdot 2$ \\
\hline $6 \cdot 7$ & $6 \cdot 9$ & $5 \cdot 3$ \\
\hline $3 \cdot 4$ & $\cdots$ & $\cdots$ \\
\hline $11 \cdot 1$ & $13 \cdot 2$ & $10 \cdot 7$ \\
\hline$\cdots$ & $\cdots$ & $7 \cdot 4$ \\
\hline .. & . & 14.7 \\
\hline$\cdots$ & $\cdots$ & $14 \cdot 1$ \\
\hline$\cdots$ & . & $9 \cdot 3$ \\
\hline$\ldots$ & $\ldots$ & $\mathbf{3 . 5}$ \\
\hline . & $\cdots$ & $\mathbf{2 \cdot 0}$ \\
\hline . & $\ldots$ & $1 \cdot 3$ \\
\hline 0.0 & . & $0 \cdot 0$ \\
\hline $0 \cdot 1$ & $\ldots$ & 0.0 \\
\hline$\cdots$ & $\cdots$ & 0.0 \\
\hline - & $0 \cdot 6$ & . \\
\hline -. & $0 \cdot 0$ & $\cdots$ \\
\hline 1.7 & .. & .. \\
\hline
\end{tabular}

* The tryptic digests were prepared by digesting $3 \mathrm{~g}$. protein with $25 \mathrm{mg}$. trypsin (1 : 250, Difco) at $37^{\circ}$ for $24 \mathrm{hr}$. The solution was then filtered, and the filtrate diluted with water to $100 \mathrm{ml}$; $\mathrm{pH}$ value of digests adjusted to 6.8. To test the effect of trypsin $25 \mathrm{mg}$. was dissolved in $100 \mathrm{ml}$. water.

$\dagger$ The mixture of B-vitamins had the following composition: $10 \mathrm{mg}$. thiamine-HCl, $10 \mathrm{mg}$. riboflavin, $10 \mathrm{mg}$. nicotinic acid, $25 \mathrm{mg}$. pyridoxin-HCl, $2 \mathrm{mg} . p$-aminobenzoic acid, $1 \mathrm{mg}$. folic acid, $100 \mathrm{mg}$. inositol, $100 \mathrm{mg}$. choline, and $30 \mu \mathrm{g}$. vitamin $B_{18}$ in $200 \mathrm{ml}$. water. The 'nucleotide mixture' contained adenylic acid, guanylic acid, uridylic acid, xanthine and thymine, $10 \mathrm{mg}$. of each in $10 \mathrm{ml}$. water. The amino-acid mixture was composed in such a way as to simulate the amino-acid composition of milk.

hydrolysates of commercial protein preparations were investigated. Tryptic hydrolysates of several proteins were strongly active in promoting the growth of the test strain, while acid hydrolysates of the same proteins were completely inactive. These properties and the heat-stability of the substance (Figs. 3 and 4) show a striking similarity of the active principle to strepogenin (Wright \& Skeggs, 1944; Sprince \& Woolley, 1945). To obtain further information on this relationship experiments were performed to determine the activity of our preparations by means of the assay for strepogenin which uses $L$. casei (Kodicek \& Mistry, 1952).

\section{Effect of different preparations on the growth of $\mathrm{L}$. casei and L. bifidus (TM 2)}

The results of an experiment to show the effect of various protein preparations on the two organisms are given in Table 4. Although the growth-promoting activity of almost all preparations tested was higher with $\boldsymbol{L}$. bifidus than with $L$. casei the results with the two organisms compare fairly closely. 
Egg albumin, blood albumin and milk were most active in both cases; gelatin and zein had very low activity. The activity of whey, and tryptic digest of whey or pepsin was much more marked with $L$. bifidus.

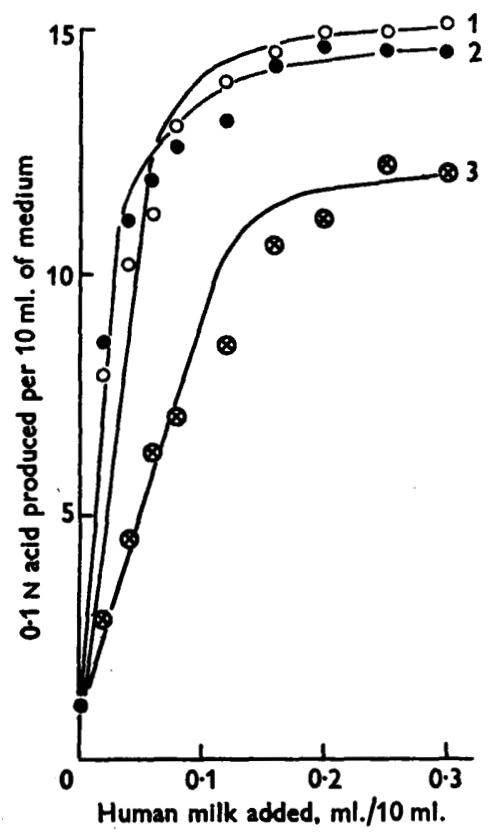

Fig. 3

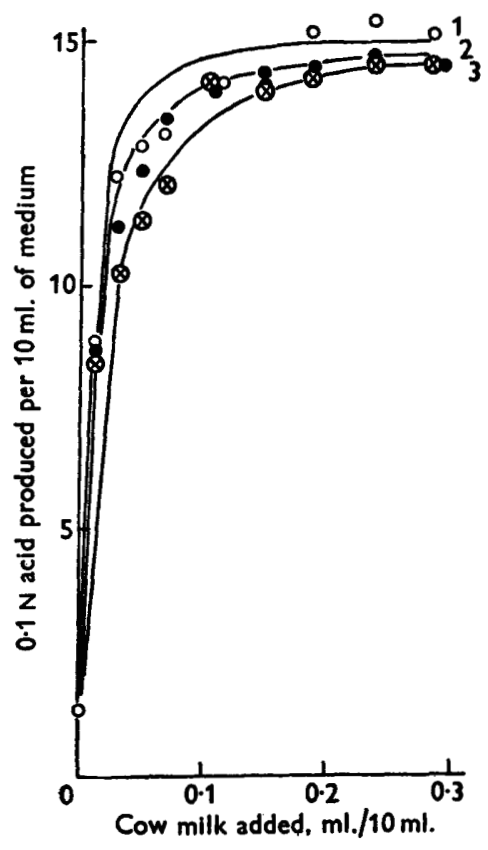

Fig. 4

Fig. 3. Effect of human milk on the growth of $L$. bifidus (TM2) in the basal medium containing cysteine $\left(100 \mu \mathrm{g} . / \mathrm{ml}\right.$.). 1 . Human milk, heated for $30 \mathrm{~min}$. at $63^{\circ}$. 2. Human milk, heated for $10 \mathrm{~min}$. at $110^{\circ}$. 3. Human milk whey, heated for $10 \mathrm{~min}$. at $110^{\circ}$.

Fig. 4. Effect of cow milk on the growth of L. bifidus (TM 2) in the basal medium containing cysteine $\left(100 \mu \mathrm{g} . / \mathrm{ml}\right.$.). 1. Milk, heated for $30 \mathrm{~min}$. at $63^{\circ} .2$. Milk, heated for $10 \mathrm{~min}$. at $110^{\circ}$. 3. Whey, heated for $10 \mathrm{~min}$. at $110^{\circ}$.

Table 4. Effect of different preparations on the growth of L. casei (ATCC 7469) and $\mathbf{L}$. bifidus (TM 2); order of activities

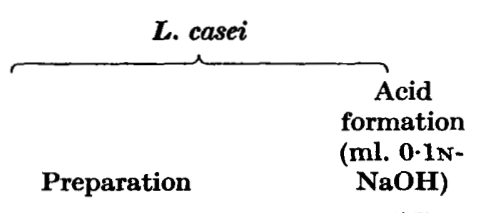

Milk

Egg albumin, tryptic digest

Blood albumin, tryptic digest

Whey

Whey, tryptic digest

Pepsin, tryptic digest

Zein, tryptic digest

Casein, tryptic digest

Gelatin, tryptic digest

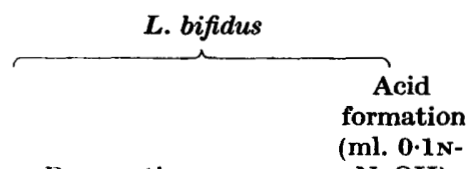

Egg albumin, tryptic digest

9.9 Blood albumin, tryptic digest $14 \cdot 1$

7.0 Milk $12 \cdot 6$

3.7 Whey, tryptic digest 10.7

3.1 Whey $10 \cdot 2$

1.6 Pepsin, tryptic digest $\quad 9 \cdot 3$

1.0 Casein, tryptic digest $7 \cdot 4$

$\mathbf{0 . 3}$ Gelatin, tryptic digest

0.0 Zein, tryptic digest $2 \cdot 0$ 
The strepogenin activity of different preparations has usually been compared with that of an arbitrary liver standard (e.g. Woolley, 1948). Since insulin digests, according to Sprince \& Woolley (1945), may be the most potent natural sources of strepogenin, Kodicek \& Mistry (1952) proposed insulin as standard in strepogenin assays. Since suitable insulin preparations were not available to the present authors, tryptic digests of egg albumin were used as an arbitrary standard. The activities of a number of preparations were compared with each other. The different protein digests were prepared by hydrolysis with trypsin for $24 \mathrm{hr}$.; with conc. $\mathrm{HCl}$ for $3 \mathrm{hr}$. at $37^{\circ}$; with conc. $\mathrm{HCl}$ for $20 \mathrm{hr}$. at $37^{\circ}$; and with conc. $\mathrm{HCl}$ for $3 \mathrm{hr}$. at $100^{\circ}$. The digests contained $4 \mathrm{mg} . / \mathrm{ml}$. in terms of starting material. The untreated preparations were dissolved at the same concentration and milk and whey were diluted to contain $4 \mathrm{mg}$. solids/ml. Each preparation was tested at three concentrations. Relative strepogenin activities (tryptic digest of egg albumin as 100) tested with $L$. bifidus TM 2 were found to be: blood albumin, tryptic digest 27; peptonized milk (Bacto-Difco) 22; yeast extract (Bacto-Difco) 22; pepsin, tryptic digest 20; proteose-peptone (Bacto-Difco) 19; milk 17; whey 17; casein, tryptic digest 16; gelatin, tryptic digest 14; trypsin, untreated 14; blood albumin, untreated 13; glutatione 13; peptone (Bacto-Difco) 10; casein, $\mathrm{HCl}$-digest, $\mathbf{3} \mathrm{hr}$. at $37^{\circ} 9$; pepsin, untreated 9 ; egg albumin, untreated 8; tryptone (Bacto-Difco) 8; neopeptone (Bacto-Difco) 6; blood albumin, HCl-digest, $3 \mathrm{hr}$. at $37^{\circ}$ 5; casein, untreated 4; casein, HCl-digest, $20 \mathrm{hr}$. at $37^{\circ} 3$; gelatin, untreated 2 ; asparagine 2 ; other acid hydrolysates were completely inactive. The corresponding activities tested with $L$. casei were: Yeast extract 220; milk 74; whey 72; blood albumin, untreated 61 ; blood albumin; tryptic digest 44; egg albumin, untreated 33. Tryptic and acid digests of casein were inactive in concentrations tested. It can be seen that the activity of milk and whey as compared with that of the tryptic digest of egg albumin was much greater for $L$. casei than for $L$. bifidus. Furthermore, yeast extract and untreated egg- and blood-albumin were more potent sources of the active substance for $L$. casei than for $L$. bifidus. The inactivity of casein preparations for $L$. casei was confirmed in this experiment.

\section{DISCUSSION}

The strains of $\boldsymbol{L}$. bifidus studied by the present authors were isolated and subcultivated under conditions reported to maintain $L$. bifidus unchanged. In fact no spontaneous clear-cut changes were observed except that the ability to develop intensive growth in the minimal medium gradually decreased. Nutritional properties characteristic of the straight rod type were not, however, observed during 5 months' work with them. The bifid morphology became less pronounced during subcultivation in vitro for some months, although bifid forms were then still present in abundance. It seems that the minimal medium employed (Hassinen et al. 1951) permits minor changes in morphology and nutritional properties of the bifid type, but that the change is not to the straight rod type. As shown by Norris et al. (1950) and by Hassinen et al. (1951) many properties of $L$. bifidus are readily changed by subcultivation in 
vitro under certain conditions, the simple nutritional requirements of the bifid type changing to the more complicated requirements of the straight rod type. It seems probable, however, that intermediates between these two main types can also develop from strains of the bifid type, and that the strains of $\boldsymbol{L}$. bifidus described in this paper must be considered as such intermediates. They were similar to the bifid type in most respects but differed from it in their requirement of the essential factor in milk. The growth-promoting factor for L. bifidus found in milk, whey, and enzymic protein hydrolysates appeared to be closely related to strepogenin. Except with casein preparations, results from comparative assays with $L$. casei and $L$. bifidus were in good agreement. Our finding of the inactivity of casein hydrolysates for $L$. casei agrees with that of Kodicek \& Mistry (1952) who made a similar observation. Wright, Fruton, Valentik \& Skeggs (1950), on the other hand, who used Lactobacillus bulgaricus as the test organism, recorded fairly high activity values for casein preparations. Again, egg albumin, which in our experiments had the highest activity, according to Wright et al. (1950) was only slightly active for $L$. bulgaricus. It appears that the term 'strepogenin' may cover different combinations of amino-acids and thus the requirements for this factor can be different with different strains and species of lactobacilli. The 'strepogenin' activity of milk and whey cannot be ascribed to any particular protein since digests of casein as well as lactalbumin were active. The relatively high potency of whey could be explained by assuming that the active substance is formed during the operations connected with the removal of protein, and is then enriched in the whey.

\section{REFERENCES}

Bergey's Manual of Determinative Bacteriology (1948), 6th ed. Ed. R. S. Breed, E. G. D. Murray and A. P. Hitchens, p. 1529. London: Baillière, Tindall and Cox.

Clegg, K. M., Kodicek, E. \& Mrstry, S. P. (1952). A modified medium for Lactobacillus casei for the assay of B-vitamins. Biochem. J. 50, 326.

Hassinen, J. B., Durbin, G. T., Tomareldi, R. M. \& Bernhart, F. W. (1951). The minimal nutritional requirements of Lactobacillus bifidus. J. Bact. 62, 771.

Kodicek, E. \& Mrstry, S. P. (1952). The microbiological assay of 'strepogenin' with Lactobacillus casei. Biochem. J. 51, 108.

Norris, R. F., Flanders, 'T., Tomarelu, R. M. \& György, P. (1950). The isolation and cultivation of Lactobacillus bifidus. A comparison of branched and unbranched strains. J. Bact. 60, 681 .

SPRINCE, H. \& Woollex, D. W. (1945). The occurrence of the growth factor strepogenin in purified proteins. J. Amer. chem. Soc. 67, 1734.

Teply, L. J. \& ElvenJem, C. A. (1945). The titrimetric determination of 'Lactobacillus casei factor' and 'folic acid'. J. biol. Chem. 157, 303.

Tissier, H. (1899). La réaction chromophile d'Escherich et le Bacterium coli. C.R. Soc. Biol., Paris, 51, 943.

Trssren, H. (1900). Recherches sur la flore intestinale normale et pathologique du nourrisson. Thèse: Université de Paris. (Quoted by E. Olsen (1949).) Studies on the intestinal flora of infants, p. 147. Copenhagen: Ejnar Munksgaard.

Tomarelu, R. M., Norris, R. F. \& György, P. (1949a). Inability of vitamin $B_{18}$ to replace the desoxyriboside requirement of Lactobacillus bifidus. J. biol. Chem. 179, 485. 
Tomarelu, R. M., Norris, R. F., György, P., Hassinen, J. B. \& Bernhart, F. W. $(1949 b)$. The nutrition of variants of Lactobacillus bifidus. J. biol. Chem. 181, 879.

Tomareli, R. M., Norris, R. F., Rose, C. S. \& György, P. (1950). The effect of fatty acids on the growth of strains of Lactobacillus bifidus. J. biol. Chem. $187,197$.

Weiss, J. E. \& RETTGer, L. F. (1938). Taxonomic relationship of Lactobacillus bifidus (Bac. bifidus (Tissier)) and Bacteroides bifidus (Eggerth). J. infect. Dis. 62, 115.

Woolney, D. W. (1948). Strepogenin activity of derivatives of glutamic acid. J. biol. Chem. 172, 71 .

Wright, L. D., Fruton, J. S., Valentik, K. A. \& Skeggs, H. R. (1950). An improved assay for 'strepogenin' based on essential nature of material for Lactobacillus bulgaricus O9. Proc. Soc. exp. Biol., N.Y. 74, 687.

Wright, L. D. \& SkEGGS, H. R. (1944). The growth factor requirements of certain streptococci. J. Bact. 48, $11 \%$.

(Received 23 February 1953) 